\title{
SCALING RESISTANCE AND AIR VOID CHARACTERISTICS IN CONCRETE CONTAINING GGBS
}

\section{J. WAWRZEŃCZYK ${ }^{1}$, A. MOLENDOWSKA ${ }^{2}$, T. JUSZCZAK ${ }^{3}$}

\begin{abstract}
In this paper we discuss the test results for concretes containing various amounts of ggbs as compared to concretes made with Portland cement. The main objective of these tests is to evaluate the influence of varying air content in such mixtures on the structure and frost resistance of concrete. The authors suggest that the approach presented here allows for a safe design of concrete mixtures in terms of their frost resistance.

The results indicate that concrete can be resistant to surface scaling even at the $\mathrm{W} / \mathrm{C}$ ratio markedly higher than 0.45. Increased addition of ggbs leads to a decrease in concrete resistance to surface scaling. Proper air entrainment is the fundamental factor for frost-resistant concrete, and the air void system has to be assessed (micropore content $\mathrm{A}_{300}$, spacing factor $\bar{L}$ ). The addition of ggbs increases pore diameters, thus, to obtain the appropriate air pore spacing factor, micropore quantities introduced have to be increased.
\end{abstract}

Keywords: scaling resistance, air entrainment, ggbs, air pore system

\section{INTRODUCTION}

Amendment to PN-EN 206 standard [10] regards ground granulated blast furnace slag as a Type II addition, as is the case with fly ash and silica fume. The use of ggbs can be applied as a cement replacement in the composition of concrete and in the water-to-cement ratio if its suitability has

\footnotetext{
${ }^{1}$ PhD., DSc., Eng., professor of KUT, Kielce University of Technology, Faculty of Civil Engineering and Architecture, Al. Tysiąclecia Państwa Polskiego 7, 25-314 Kielce, Poland, e-mail: zmsjw@tu.kielce.pl

${ }^{2}$ PhD., Eng., Kielce University of Technology, Faculty of Civil Engineering and Architecture, Al. Tysiąclecia Państwa Polskiego 7, 25-314 Kielce, Poland, e-mail: agam@tu.kielce.pl

${ }^{3}$ PhD., Eng., Kielce University of Technology, Faculty of Civil Engineering and Architecture, Al. Tysiąclecia Państwa Polskiego 7, 25-314 Kielce, Poland
} 
been established based on either the k-value concept or the equivalent concrete performance concept.

When CEM I or CEM II/A is combined with ggbs, PN-EN 206 recommends that the $\mathrm{k}$ factor equal 0.6 . The maximum ggbs amount has to meet the requirement of ggbs/cement $\leq 1.0$ by mass. If a greater amount is used, the excess shall not be taken into account for the calculation of the water/(cement $+\mathrm{k}$ x ggbs) ratio and the minimum cement content. New IBDiM Guidelines [15] allow the use of ggbs cement in road pavements, but the mineral addition is not accounted for in the calculation of $\mathrm{W} / \mathrm{C} \leq 0.45$ (therefore, $\mathrm{k}=0$ ).

Adopting a constant value of $\mathrm{k}$ is controversial. Sanjuan et al. [12], Chromá et al. [3] and the authors of this paper [14] addressed the issue of the $\mathrm{k}$ factor for ggbs. Analysis of the results suggests that:

- the k-value decreases with increasing amount of ggbs,

- the k-value increases with increased fragmentation of ggbs (the larger the surface area, the higher the chemical activity of the addition),

- the k-values are higher for cements with lower strength,

- the value of $\mathrm{k}$ to be applied should vary depending on the concrete characteristic being investigated.

Sanjuan et al. [12] emphasize that adopting a generalized value of $\mathrm{k}$ is complicated and risky. In national standards and guidelines, these values should be adopted carefully and with safe criteria. The values determined for a given case may not guarantee the reproducibility of the results in other cases. At the current state of the art, the k-value should be determined experimentally. Similar conclusions have been reported by other researchers, including Chromá et al. [3].

Another method of solving the durability problem involves the use of the equivalent concrete performance concept (ECPC) and the equivalent performance of combinations concept (EPCC). The equivalent performance concepts are usually considered in respect of the strength of concrete, and in France [6], Belgium, [13] and the Netherlands [2] also with regard to frost resistance. In Poland ECPC is not used or considered and PN-EN 206 standard refers interested parties to CEN/TR 16639 for details [2].

It is well known that surface scaling is a major issue for concretes made with ggbs. The resistance to surface scaling is associated with the characteristics of the near-surface concrete layer, which is affected by the W/B ratio, airentrainment, microcracks, sedimentation and carbonation. Some standards impose the limits on the ggbs amounts due to frost resistance issue. For the same reason, ACI guidelines [1] recommend reducing the ggbs addition to 50\%. National annexes to the 206 
standard [9] calculate the amount of ggbs added at XF4 exposure class conditional upon the strength class of CEM III: for $32,5 \mathrm{R}$ up to $50 \%$, for $42,5 \mathrm{R}$ more than $50 \%$, and over $80 \%$ for structures operating at seawater.

It is generally accepted that air entrainment improves the frost durability of concrete. However, combined use of plasticizers, air entraining admixtures and ggbs in one mix may lead to problems with the stability of the air void system. The air content alone cannot be used as an adequate indicator of the quality of the concrete. The dosage of the air entraining agent used, which provides a suitable air volume, does not ensure proper spacing of the bubbles and consequently, does not protect against freezing [7].

Giergiczny et al. [5] reported a deterioration of air pore system parameters in the concrete mix with ggbs - at the given air content the bubbles had larger diameters - the $\bar{L}$ factor increased by about $0.10 \mathrm{~mm}$. The deterioration of air entrainment efficiency was also observed by Deja [4], who stated that air entrained concrete containing ggbs admixture, resistant to surface scaling, could be obtained at the $\mathrm{W} / \mathrm{C}$ ratio greater than 0.45 .

The knowledge of the chemical composition of cement and ggbs is not sufficient for determining the final durability effect. Each material variant needs to be verified experimentally to qualify the adequacy of the adopted solution.

This paper shows the results from tests of concrete samples with different ggbs content relative to the concrete made with Portland cement. The aim of these studies also included the evaluation of how the variable amount of air in the mixes (air content fluctuations) affects the air void system and freeze-thaw durability of concrete. In the authors' view, this approach contributes to the safe design of concretes from the frost resistance standpoint.

\section{MATERIALS AND METHODS}

The tests were performed on air entrained and non-air entrained concretes. All concretes consisted of the same water-to-binder ratio, W/B=0.42 ( $\mathrm{B}=\mathrm{C}+\mathrm{GGBS})$. They were made with $\mathrm{CEM}$ I $42,5 \mathrm{~N}$ NA and varied amounts of ggbs, with the $\mathrm{C}+\mathrm{GGBS}$ amount remaining constant in all series. The ggbs content in the binder was $0,15,35$, and $55 \%$. The amount of air entraining admixture, AEA, was selected experimentally to be able to obtain three levels of air entrainment, about $2 \%, 5-6 \%$, and $8 \%$, in each of the four series (with different ggbs content).

The effect of the quantity of slag and level of air entrainment on physical properties, porosity structure and resistance to surface scaling was determined in this study. 
Four separate batches of concrete were prepared with various slag content. Each sample contained one non-air entrained concrete and three or four concretes with different levels of air entrainment.

The concretes were made from Portland cement CEM I 42.5 R, ground slag, natural sand 0-2 mm (S), coarse aggregate - basalt 2-8, 8-16 mm (47:53\%), and an air entraining agent (AEA). A plasticizer was used to provide stable consistency S3. Table 1 summarises the data concerning the ggbs chemical composition and physical characteristics. The composition and selected properties of the concretes are compiled in Table 2 .

Table 1. Chemical composition and physical properties of ggbs

\begin{tabular}{|c|c|c|}
\hline Parameter & Unit & Value \\
\hline $\mathrm{CaO}$ & $\%$ & 44,8 \\
\hline $\mathrm{SiO}_{2}$ & $\%$ & 40,1 \\
\hline $\mathrm{MgO}$ & $\%$ & 5,9 \\
\hline $\mathrm{Al}_{2} \mathrm{O}_{3}$ & $\%$ & 7,0 \\
\hline $\mathrm{Mn}$ & $\%$ & 0,2 \\
\hline $\mathrm{Fe}_{\text {total }}$ & $\%$ & 0,3 \\
\hline $\mathrm{Na}_{2} \mathrm{O}$ & $\%$ & 0,23 \\
\hline $\mathrm{K}_{2} \mathrm{O}$ & $\%$ & 0,49 \\
\hline $\mathrm{Glass}_{\mathrm{shase}}$ & $\%$ & 91,0 \\
\hline Surface area & $\mathrm{cm}^{2} / \mathrm{g}$ & 4445 \\
\hline Density & $\mathrm{g} / \mathrm{cm}^{3}$ & 2,88 \\
\hline $\mathrm{x}$ & $\mu \mathrm{m}$ & 15,87 \\
\hline
\end{tabular}

Table 2. Composition and selected properties of concrete mixtures

\begin{tabular}{|c|c|c|c|c|c|c|c|c|c|}
\hline Series & $\mathbf{W} / \mathbf{C}$ & $\begin{array}{c}\mathbf{C} \\
\mathbf{k g} / \mathbf{m}^{\mathbf{3}}\end{array}$ & $\begin{array}{c}\mathbf{G G B S} \\
\mathbf{k g} / \mathbf{m}^{\mathbf{3}}\end{array}$ & $\begin{array}{c}\mathbf{S} \\
\mathbf{k g} / \mathbf{m}^{\mathbf{3}}\end{array}$ & $\begin{array}{c}\text { Basalt } \\
\mathbf{k g} / \mathbf{m}^{\mathbf{3}}\end{array}$ & $\begin{array}{c}\mathbf{S P L} \\
\mathbf{\%} \mathbf{m . c}\end{array}$ & $\begin{array}{c}\mathbf{A E A} \\
\mathbf{\%} \mathbf{m} . \mathbf{c}\end{array}$ & $\begin{array}{c}\boldsymbol{\rho} \\
\mathbf{k g} / \mathbf{m}^{\mathbf{3}}\end{array}$ & $\begin{array}{c}\mathbf{Z p} \\
\mathbf{\%}\end{array}$ \\
\hline B1-0 & 0.42 & 359 & 0 & 668 & 1419 & 0.52 & 0 & 2599 & 2.6 \\
\hline B1-1 & 0.42 & 355 & 0 & 660 & 1403 & 0.49 & 0.05 & 2569 & 3.7 \\
\hline B1-2 & 0.42 & 346 & 0 & 645 & 1370 & 0.49 & 0.08 & 2509 & 5.8 \\
\hline B1-3 & 0.42 & 332 & 0 & 618 & 1314 & 0.49 & 0.10 & 2406 & 8.6 \\
\hline B2-1 & 0.50 & 299 & 53 & 653 & 1387 & 0.63 & 0 & 2541 & 3.5 \\
\hline B2-2 & 0.50 & 291 & 51 & 636 & 1352 & 0.58 & 0.09 & 2478 & 6.3 \\
\hline B2-3 & 0.50 & 284 & 50 & 619 & 1316 & 0.70 & 0.22 & 2413 & 8.0 \\
\hline B3-1 & 0.65 & 229 & 123 & 652 & 1385 & 0.70 & 0 & 2539 & 3.8 \\
\hline B3-2 & 0.65 & 223 & 120 & 636 & 1352 & 0.70 & 0.09 & 2478 & 6.2 \\
\hline B3-3 & 0.65 & 221 & 119 & 630 & 1340 & 0.65 & 0.13 & 2457 & 7.8 \\
\hline B4-1 & 0.94 & 160 & 195 & 656 & 1394 & 0.95 & 0 & 2556 & 3.8 \\
\hline B4-2 & 0.94 & 157 & 192 & 645 & 1372 & 0.90 & 0.13 & 2516 & 5.4 \\
\hline B4-3 & 0.94 & 154 & 188 & 632 & 1343 & 0.95 & 0.25 & 2463 & 7.1 \\
\hline
\end{tabular}


The scope of testing included measuring the consistency of the concrete via use of the slump test, determining the density by volume method and air content with the use of the pressure method ( $\mathrm{Zp}$ ). The assessed parameters of the hardened concrete included compressive strength at 28 days of curing $\left(\mathrm{f}_{\mathrm{cm}}^{\prime}\right)$, water absorption $\left(\mathrm{n}_{\mathrm{w}}\right)$, freeze-thaw resistance - resistance to surface scaling $\left(\mathrm{m}_{56}\right)$ - freezing the specimens in a $3 \% \mathrm{NaCl}$ solution (slab test), and porosity characteristics (A, $\left.\mathrm{A}_{300}, \bar{L}, \alpha\right)$ to $\mathrm{PN}$ EN 480-11:1998 [11].

Compressive strength to PN-EN 12390-3:2011 and water absorption to the Polish standard PN-88/B06250 were measured on $10 \times 10 \times 10 \mathrm{~cm}$ cubes. The resistance to surface scaling was assessed with the use of the slab method in accordance with PKN-CEN/TS 12390-9:2007 [8]. The polished sections were prepared and the characteristics of porosity were determined to PN-EN 480-11 [11] via the chord counting method. Automatic image analysis was performed with the use of the set-up composed of a stereo microscope, a CCD camera and the motorized stage.

\section{TESTS RESULTS AND DISCUSSION}

Table 3 compiles the test results for the hardened concretes. The concretes have high strength and a relatively low water absorption by weight in the range $3.7-4.2 \%$. Depending on the quantity of air introduced, it is possible to obtain concrete in C 30/37-C 45/55 strength classes.

Table 3. Properties of hardened concrete specimens

\begin{tabular}{|c|c|c|c|c|c|c|c|}
\hline Series & $\begin{array}{c}\mathbf{f}^{\prime} \mathrm{cm} \\
\mathrm{MPa}\end{array}$ & $\begin{array}{l}\mathbf{n}_{\mathbf{w}} \\
\%\end{array}$ & $\begin{array}{c}m_{56} \\
\mathrm{~kg} / \mathrm{m}^{2}\end{array}$ & $\begin{array}{l}\mathbf{A} \\
\% \\
\end{array}$ & $\begin{array}{c}\mathbf{A}_{300} \\
\%\end{array}$ & $\begin{array}{c}\alpha \\
\mathbf{m m}^{-1}\end{array}$ & $\begin{array}{c}\bar{L} \\
\mathbf{m m}\end{array}$ \\
\hline B1-0 & 73.2 & 4.0 & 1.329 & 3.92 & 0.82 & 15.24 & 0.35 \\
\hline B1-1 & 69.8 & 4.1 & 0.169 & 5.17 & 2.46 & 23.00 & 0.20 \\
\hline B1-2 & 64.9 & 4.0 & 0.023 & 6.59 & 3.37 & 25.06 & 0.15 \\
\hline B1-3 & 60.8 & 4.2 & 0.045 & 8.90 & 4.85 & 22.94 & 0.12 \\
\hline B2-1 & 74.7 & 3.7 & 0.327 & 2.99 & 0.60 & 16.61 & 0.38 \\
\hline B2-2 & 62.7 & 4.1 & 0.145 & 6.03 & 2.75 & 19.58 & 0.23 \\
\hline B2-3 & 55.3 & 4.0 & 0.030 & 7.14 & 3.68 & 19.83 & 0.20 \\
\hline B3-1 & 68.9 & 4.0 & 1.788 & 3.88 & 0.70 & 11.66 & 0.46 \\
\hline B3-2 & 66.6 & 4.1 & 0.493 & 6.22 & 2.78 & 19.81 & 0.21 \\
\hline B3-3 & 58.5 & 4.0 & 0.114 & 8.84 & 4.54 & 23.20 & 0.12 \\
\hline B4-1 & 60.4 & 3.8 & 2.355 & 4.32 & 0.98 & 11.59 & 0.44 \\
\hline B4-2 & 56.9 & 3.7 & 2.021 & 6.21 & 2.88 & 15.38 & 0.28 \\
\hline B4-3 & 53.1 & 3.8 & 0.773 & 6.92 & 5.23 & 22.80 & 0.13 \\
\hline
\end{tabular}


Test results show that the increase in ggbs and air content does not lead to any significant changes in water absorption values, while the air content contributes substantially to the drop in the compressive strength of the concrete.

Figure 1 a-d shows the resistance of the concrete to surface scaling. Concrete specimens B1-0, B31 , B4-1, and B4-2 failed the $1.0 \mathrm{~kg} / \mathrm{m}^{2}$ requirement, with the mass of the scaled off material in the range $1.329-2.355 \mathrm{~kg} / \mathrm{m}^{2}$. Concrete specimens B1-2, B1-3, and B2-3 showed very good resistance with a marginal scaling mass loss of $\left(0.023-0.045 \mathrm{~kg} / \mathrm{m}^{2}\right)$. Specimens B1-1, B2-1, B2-2, B3-2 and B3-3 had a scaling mass loss of $0.114-0.493 \mathrm{~kg} / \mathrm{m}^{2}$, that is, they showed good resistance to freezethaw cycles in $\mathrm{NaCl}$ solution. The freeze-thaw resistance of specimens B4-3 can be evaluated as satisfactory (scaling mass loss of $0.773 \mathrm{~kg} / \mathrm{m}^{2}$ ).

a)

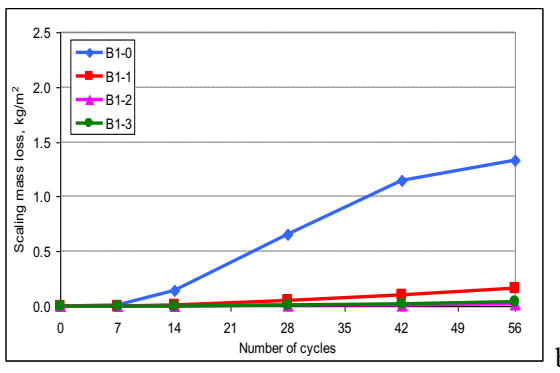

b)
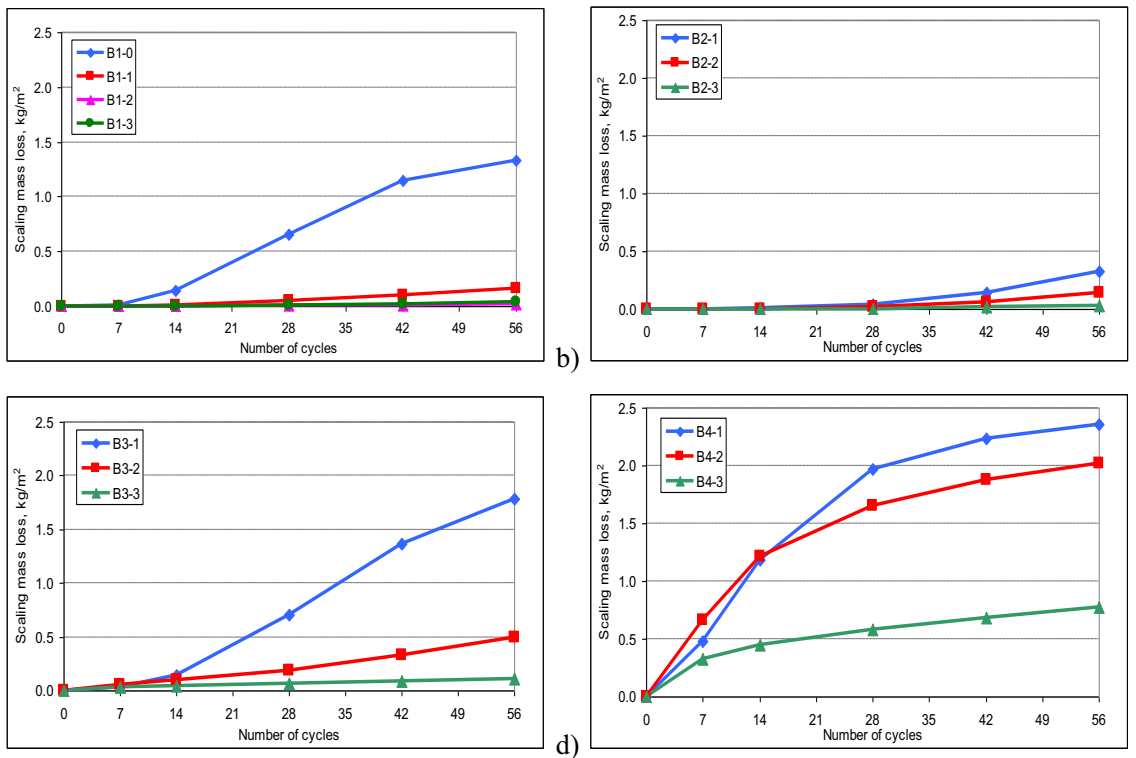

Fig. 1. Scaling mass loss - mean values

a) specimens B1-0-B1-3, b) specimens B2-1-B2-3, c) specimens B3-1-B3-3, d) specimens B4-1-B4-3

Analysis of the relationships between the W/C (water/cement) ratio and mass loss $\mathrm{m}_{56}$ (Fig. 2) indicates that at the assumed low air entrainment level, the concrete meets the condition that $\mathrm{m}_{56}<1.0 \mathrm{~kg} / \mathrm{m}^{2}$ at $\mathrm{W} / \mathrm{C} \leq 0.55$.

Figure 3 shows the relationship between air content $(\mathrm{Zp})$ and mass loss $\left(\mathrm{m}_{56}\right)$. The amount of slag incorporated has a decisive impact on the quantity of scaling material. This is especially clear at the 
lower content of air. At the higher air content, the differences are less visible. At the same air content, the concrete specimens with greater slag amounts show larger mass losses. If the air content is too low (the bubbles are too far apart) and the slag content is high, the resistance to scaling damage is noticeably reduced. Proper air entrainment is guarantees that the concrete will be resistant to freeze and thaw damage.

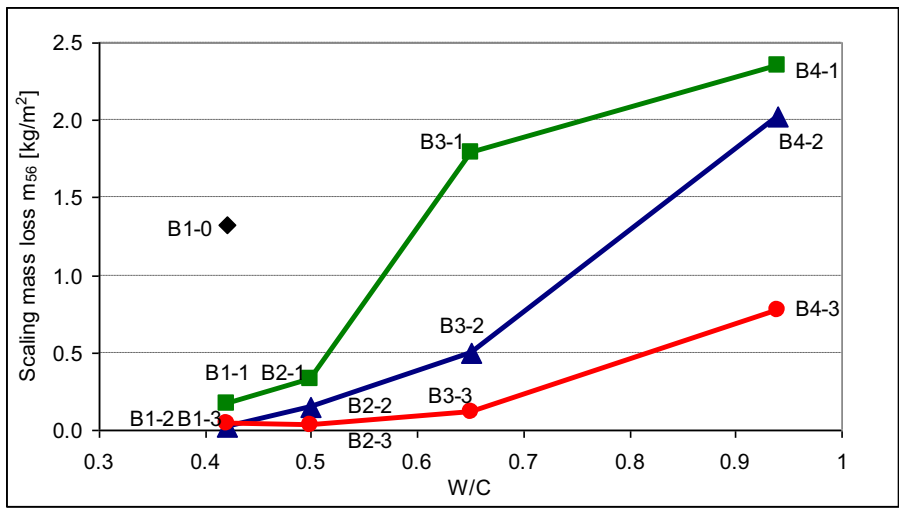

Fig. 2. Relationship between the $\mathrm{W} / \mathrm{C}$ ratio and mass loss $\left(\mathrm{m}_{56}\right)$

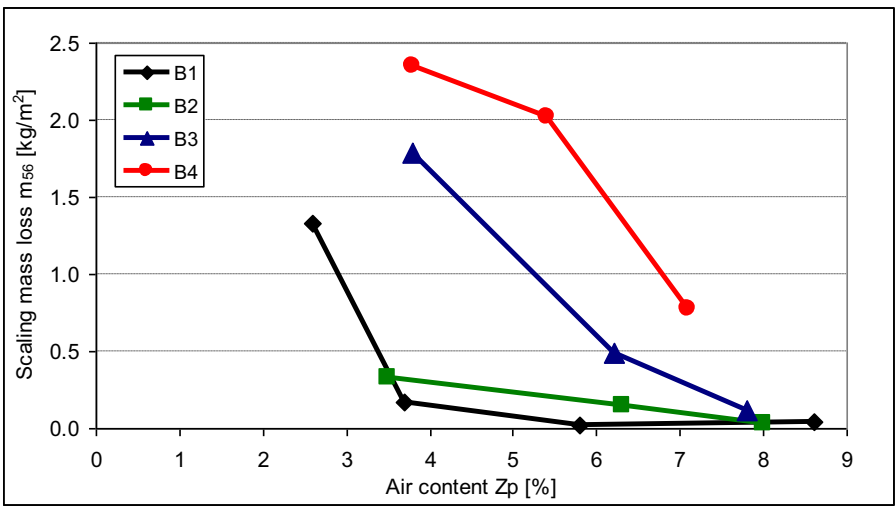

Fig. 3. Relationship between air content $(\mathrm{Zp})$ and mass loss $\left(\mathrm{m}_{56}\right)$ 


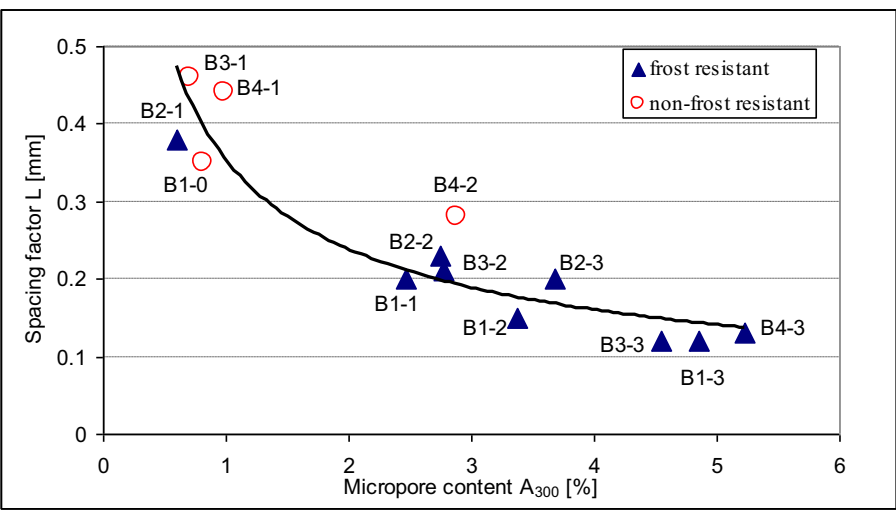

Fig. 4. Relationship between spacing factor $(\bar{L})$ and micropore content $\left(\mathrm{A}_{300}\right)$

Figure 4 shows the dependence of the spacing factor $\bar{L}$ on the micropore content $\left(\mathrm{A}_{300}\right)$. Microscopic examination indicated that the air content (A) ranged from 2.99 to $8.90 \%$ when the micropore content $\left(\mathrm{A}_{300}\right)$ ranged from 0.60 to $5.23 \%$. The values of the spacing factor, $\bar{L}$, for the concretes under investigation were in the range of 0.12 to $0.46 \mathrm{~mm}$. The addition of slag causes an increase in the air bubble size, and in order to obtain the proper spacing $\bar{L}$ at the level of $0.20-0.25$ $\mathrm{mm}$, it is necessary to incorporate at least $2.5 \%$ of micropores $\mathrm{A}_{300}$. In the airentrained concretes with a significant content of micropores $\mathrm{A}_{300}(2.46-5.23 \%$ ), the values of the $\alpha$ parameter are low, ranging from 15.38 to $25.06 \mathrm{~mm}^{-1}$. These results confirm that the addition of slag contributes to problems with proper air entrainment.

\section{CONCLuSiOnS}

Based on the analysis of the results from the tests performed on concrete specimens made with a binder containing $0-55 \%$ slag, at the constant $\mathrm{W} / \mathrm{B}=0.42$ ratio and three air entrainment levels, the following conclusions were formulated:

1. An increase in slag addition leads to a reduced surface scaling resistance of concrete.

2. Tests results confirm that concrete can be resistant to surface scaling when the $\mathrm{W} / \mathrm{C}$ ratio is considerably higher than 0.45 . Thus, the guidelines [15] relating to the paving concrete design introduce serious limitations.

3. The fundamental factor for producing concrete resistant to surface scaling is its proper air entrainment. 
4. The addition of slag contributes to the problems with proper air entrainment of concrete. The air bubbles grow in size, as confirmed by the fact that at a considerable amount of micropores $\mathrm{A}_{300}$, the values of $\alpha$ are quite low (smaller than $20 \mathrm{~mm}^{-1}$ ). The test results indicate that in order to obtain the desired spacing factor $(\bar{L})$ at the level of $0.20 \div 0.25 \mathrm{~mm}$, at least $2.5 \%$ of micropores $\mathrm{A}_{300}$ have to be incorporated.

5. In the authors opinion, comparative testing of scaling resistance through direct freezing and thawing is the fundamental method of concrete frost resistance evaluation.

\section{REFERENCES}

1. ACI Committee 226: Ground granulated blast-furnace slag as a cementitious constituent in concrete. ACI Materials Journal, Vol. 84, No. 4: 327-342, 1987.

2. CEN/TR 16639 Use of k-value concept, equivalent concrete performance concept and equivalent performance of combinations concept.

3. M. Chromá, P. Rovnaniková, B. Teplý, K. Bergmeister, A. Strauss, "Concrete durability and the k-value concept", Cement Wapno Beton 2/2014: 81-92.

4. J. Deja, "Freezing and de-icing salt resistance of blast furnace slag concretes", Cement and Concrete Composites 25: 357-361, 2003.

5. Z. Giergiczny, M.A. Glinicki, M. Sokołowski, M. Zieliński, “Air void system and frost-salt scaling of concrete containing slag-blended cement”, Construction and Building Materials 23: 2451-2456, 2009.

6. L. Linger, E. Roziere, A. Loukili, F. Cussigh, P. Rougeau, "Concrete equivalent performance concept for durability - an operational guide for the comparative approach" Proceedings of The Fourth International Congress, Mumbai, pp. 540-547, 14 February 2014.

7. M. Pigeon, J. Marchand, R. Pleau, "Frost resistant concrete", Construction and Building Materials, Vol. 10, No. 5: 339-348, 1996.

8. PKN-CEN/TS 12390-9:2007 Testing Hardened Concrete - Part 9: Freeze-Thaw Resistance - Scaling.

9. PN-B-06265:2004. Polish National Supplement: PN-EN 206-1:2003 Concrete - Specification, performance, production and conformity.

10. PN-EN 206 Concrete - Specification, performance, production and conformity.

11. PN-EN 480-11:1998. Admixtures for concrete, mortar and grout - Test methods - Part 11: Determination of air void characteristics in hardened concrete.

12. M.A. Sanjuan, A. Pineiro, O. Rodriguez, "Ground granulated blast furnace slag efficiency coefficient (k value) in concrete. Applications and limits”, Materiales de Construcción, Vol. 61, No. 302: 303-313, abril-junio 2011.

13. G. De Schutter, "Belgian Implementation of the ECPC-Concept Following EN 206-1", XII DBMC International Conference on Durability of Building Materials and Components PORTO-PORTUGAL, April 12th-15th, 2011.

14. J. Wawrzeńczyk, T. Juszczak, A. Molendowska, "Wpływ zawartości granulowanego żużla wielkopiecowego w spoiwie cementowym na mrozoodporność betonu" - artykuł przyjęty do druku w czasopiśmie Cement Wapno Beton.

15. Wymagania techniczne dla betonowych nawierzchni drogowych Etap III. IBDIM. Warszawa 2010. 


\section{LIST OF FIGURES AND TABLES:}

Fig. 1. Scaling mass loss - mean values a) specimens B1-0-B1-3, b) specimens B2-1-B2-3, c) specimens B31-B3-3, d) specimens B4-1-B4-3

Rys. 1. Ubytek masy betonów - wartości średnie a) betony B1-0-B1-3, b) betony B2-1-B2-3, c) betony B3-1B3-3, d) betony B4-1-B4-3

Fig. 2. Relationship between the $\mathrm{W} / \mathrm{C}$ ratio and mass loss $\left(\mathrm{m}_{56}\right)$

Rys. 2. Zależność pomiędzy stosunkiem W/C a ubytkiem masy $\left(\mathrm{m}_{56}\right)$

Fig. 3. Relationship between air content $(\mathrm{Zp})$ and mass loss $\left(\mathrm{m}_{56}\right)$

Rys. 3. Zależność pomiędzy zawartością powietrza (Zp) a ubytkiem masy $\left(\mathrm{m}_{56}\right)$

Fig. 4. Relationship between spacing factor $(\bar{L})$ and micropore content $\left(\mathrm{A}_{300}\right)$

Rys. 4. Zależność pomiędzy rozstawem pęcherzyków powietrza $(\bar{L})$ a zawartością mikroporów $\left(\mathrm{A}_{300}\right)$

Tab. 1. Skład chemiczny i właściwości fizyczne żużla

Tab. 1. Chemical composition and physical properties of ggbs

Tab. 2. Composition and selected properties of concrete mixtures

Tab. 2. Skład i wybrane właściwości mieszanek betonowych

Tab. 3. Properties of hardened concrete specimens

Tab. 3. Właściwości próbek stwardniałych betonów 


\section{ODPORNOŚĆ NA POWIERZCHNIOWE LUSZCZENIE I CHARAKTERYSTYKA PORÓW POWIETRZNYCH BETONÓW ZAWIERAJĄCYCH ŻUŻEL}

Keywords: powierzchniowe łuszczenie, napowietrzanie, żużel, struktura porów powietrznych

\section{STRESZCZENIE:}

W artykule przedstawiono wyniki badań betonów z różną zawartością żużla w stosunku do betonów wykonanych $\mathrm{z}$ cementem portlandzkim. Celem badań była także ocena w jaki sposób zróżnicowana ilość powietrza w takich mieszankach (wahania ilości powietrza w mieszance) wpływa na strukturę porów powietrznych i mrozoodporność betonu. Zdaniem autorów takie podejścia pozwala na bezpieczne projektowanie betonów z punktu widzenia ich mrozoodporności.

Nowelizacja normy PN-EN 206 [10] traktuje mielony granulowany żużel wielkopiecowy jako dodatek typu II, podobnie jak ma to miejsce w przypadku popiołu lotnego i pyłu krzemionkowego. Dodatek żużla można uwzględnić w składzie betonu, w ramach zawartości cementu oraz wartości współczynnika woda/cement, jeśli ustalono jego przydatność w oparciu o koncepcję współczynnika k lub koncepcję równoważnych właściwości użytkowych.

Przy stosowaniu żużla razem z cementami CEM I i CEM II/A norma PN-EN 206 zaleca przyjmowanie współczynnika $\mathrm{k}$ równego 0,6 . Zaleca się także, aby maksymalna ilość żużla spełniała warunek ggbs/cement $\leq 1,0$ masowo. Przy stosowaniu większych ilości żużla zaleca się nieuwzględnianie jego nadmiaru w obliczeniach współczynnika woda/(cement + k x ggbs) i minimalnej zawartości cementu. Z kolei nowe Wytyczne IBDiM [15] dopuszczają do stosowania w nawierzchniach drogowych cementy mieszane (w tym hutniczy) przyjmując, że do wskaźnika W/C $\leq 0,45$ nie wlicza się dodatku mineralnego (więc $\mathrm{k}=0$ ).

Przyjmowanie współczynnika k na stałym poziomie jest sprawą dyskusyjną. Zagadnienie współczynnika k dla żużla zostało szerzej przedstawione w pracach Sanjuan i inni [12], Chromá i inni [3] oraz w pracy autorów [14]. Sanjuan i inni [12] podkreślają, że przyjęcie generalnej wartości współczynnika k jest skomplikowane i ryzykowne. Wartości $\mathrm{k}$ zalecane w krajowych normach i wytycznych muszą być określane ostrożnie, przyjmując bezpieczne kryteria. Wartości wyznaczone dla danego przypadku mogą bowiem nie gwarantować powtarzalności wyników w innych przypadkach. Przy obecnym stanie wiedzy wartość k powinna być wyznaczana doświadczalnie. Podobne wnioski przedstawiają inni badacze m.in. Chromá i inni [3].

Innym sposobem rozwiązania problemu trwałości jest zastosowanie koncepcji równoważnych właściwości betonu ECPC oraz koncepcji kombinacji równoważnych właściwości użytkowych EPCC. Koncepcja równoważnych właściwości użytkowych jest zazwyczaj rozważana w odniesieniu do wytrzymałości betonu a we Francji [6], Belgii [13] i Holandii [2] również w odniesieniu do mrozoodporności. W Polsce temat koncepcji równoważnych właściwości użytkowych nie jest raczej dyskutowany i norma PN-EN 206 odsyła po bardziej szczegółowe informacje do CEN/TR 16639 [2].

Generalnie wiadomo, że w przypadku betonów wykonanych z dodatkiem ggbs występują problemy z uzyskaniem odporności na powierzchniowe łuszczenie. Odporność ta związana jest z charakterystyką przypowierzchniowej warstwy betonu i wpływ na nią mają: stosunek W/S, napowietrzenie, mikrorysy, sedymentacja, karbonatyzacja. Niektóre normy ograniczają ilość dodatku żużla w kontekście mrozoodporności. Zalecenia ACI [1] z uwagi na mrozoodporność ograniczają dodatek żużla do 50\%. Krajowe uzupełnienia do normy 206 [9] uzależniają ilość dodawanego żużla w klasie ekspozycji XF4 od klasy cementu CEM III: dla klasy 32,5R do 50\%, przy 42,5R powyżej $50 \%$, powyżej $80 \%$ dla budowli eksploatowanych w wodzie morskiej. 
Ogólnie panuje zgodna opinia, że napowietrzenie poprawia mrozoodporność betonu. Jednak jednoczesne stosowanie domieszek plastyfikujących, napowietrzających i żużla często powoduje problemy z uzyskaniem stabilnej struktury porów powietrznych. Badanie tylko samej zawartości powietrza w mieszance betonowej nie jest wystarczające do oceny jakości betonu. Dawki domieszki napowietrzającej, które zapewniają odpowiednią objętość powietrza często nie zapewniają odpowiedniego rozstawu pęcherzyków powietrznych, a tym samym nie zapewniają odpowiedniej ochrony przed zamarzaniem [7]. Znajomość składu chemicznego cementu i żużla nie jest wystarczająca, żeby określić efekt końcowy związany z trwałością betonu. Przy każdym wariancie materiałowym istnieje potrzeba doświadczalnego zweryfikowania poprawności przyjętego rozwiązania.

Badania przeprowadzono na betonach napowietrzonych i nienapowietrzonych. Wszystkie betony miały stały wskaźnik $\mathrm{W} / \mathrm{S}=0.42(\mathrm{~B}=\mathrm{C}+\mathrm{GGBS})$. Betony zostały wykonane $\mathrm{z}$ cementem CEM I 42,5N NA i z różną ilością dodatku żużla, przy czym ilość C+GGBS była stała dla wszystkich serii. Zawartość żużla w spoiwie wynosiła: 0, 15, 35 i 55\%.

Ilość domieszki napowietrzającej AEA dobierana była doświadczalnie, aby w ramach każdej z czterech serii (różnej zawartości żużla) uzyskać napowietrzenie mieszanki betonowej na trzech poziomach: ok. 2\%, 5-6\% i 8\%.

Badania podzielono na 4 serie betonów różniące się zawartością żużla. W ramach każdej serii wykonano jeden beton nienapowietrzony i trzy lub cztery betony o różnym stopniu napowietrzenia. Do wykonania betonów zastosowano cement portlandzki CEM I $42.5 \mathrm{R}$, żużel mielony, piasek naturalny 0-2 mm, kruszywo grube - bazalt 2-8, 8-16 mm oraz środek napowietrzający (AEA). W celu uzyskania stałej konsystencji S3 stosowano plastyfikator.

Zakres badań dla mieszanki betonowej obejmował wyznaczenie konsystencji metodą opadu stożka, gęstości objętościowej, zawartości powietrza metodą ciśnieniową (Zp). Zakres badań stwardniałego betonu obejmował określenie: wytrzymałości na ściskanie $\left(\mathrm{f}_{\mathrm{cm}}{ }_{\mathrm{cm}}\right)$, nasiąkliwości $\left(\mathrm{n}_{\mathrm{w}}\right)$, mrozoodporności - odporność na powierzchniowe łuszczenie $\left(\mathrm{m}_{56}\right)$ zamrażanie próbek w $3 \%$ roztworze $\mathrm{NaCl}$ (metoda slab test), charakterystyk porowatości (A, $\left.\mathrm{A}_{300}, \bar{L}, \alpha\right)$.

Analiza zależności pomiędzy stosunkiem W/C a ubytkiem masy $\mathrm{m}_{56}$ pokazuje, że zakładając niski poziom napowietrzenia beton spełnia warunek $\mathrm{m}_{56}<1,0 \mathrm{~kg} / \mathrm{m}^{2}$ przy $\mathrm{W} / \mathrm{C} \leq 0,55$. Ilość dodatku żużla w sposób decydujący wpływa na ilość złuszczonego materiału. Jest to szczególnie widoczne przy mniejszej zawartości powietrza. Przy dużej ilości powietrza różnice są mniej widoczne. Przy tej samej ilości powietrza betony z większą ilością żużla wykazują większe ubytki. Zbyt mała zawartość powietrza (zbyt duży rozstaw pęcherzyków) przy dużej zawartości żużla powodują wyraźny wzrost uszkodzeń powierzchni betonu. Prawidłowe napowietrzenie jest podstawowym warunkiem uzyskania w pełni mrozoodpornego betonu.

Na podstawie badań mikroskopowych betonów stwierdzono, że ilość powietrza (A) wynosiła od 2,99 do 8,90\%, przy zawartości mikroporów $\left(\mathrm{A}_{300}\right)$ od 0,60 do 5,23\%. Wartości współczynnika $\bar{L}$ dla badanych betonów mieszczą się w szerokich granicach od 0,12 do $0,46 \mathrm{~mm}$. Dodatek żużla powoduje wzrost wielkości pęcherzyków powietrza i aby uzyskać rozstaw pęcherzyków powietrza $\bar{L}$ na poziomie $0,20-0,25 \mathrm{~mm}$ konieczne jest wprowadzenie co najmniej $2,5 \%$ mikroporów $\mathrm{A}_{300}$. W betonach napowietrzonych, przy znacznej zawartości mikroporów (2.46-5.23\%) wartości parametru $\alpha$ są dosyć małe, w granicach $15.38-25.06 \mathrm{~mm}^{-1}$. Wyniki te potwierdzają, że w przypadku stosowania dodatku żużla występują problemy z właściwym napowietrzeniem. Zdaniem autorów przeprowadzenie badań porównawczych odporności na powierzchniowe łuszczenie metodą bezpośredniego zamrażania-rozmrażania jest podstawowym sposobem oceny mrozoodporności betonu. 